\title{
EFFECTS OF ALPINIA GALANGA POWDER ON PHYTOPHTHORA CAPSICI LEIONIAN IN VITRO
}

\author{
Joko Prasetyo, Subli Mujim, and Cipta Ginting ${ }^{1}$
}

\begin{abstract}
ABSTRAK
Pengaruh Alpinia galanga terhadap Phytophthora capsici Leionian secara in vitro. Penelitian telah dilakukan untuk mengetahui pengaruh tepung beberapa bagian dan konsentrasi $A$. galanga terhadap jari-jari koloni dan produksi zoospora $P$. capsici. Percobaan dilakukan secara faktorial $(4 \times 4)$ dalam rancangan acak lengkap dengan tiga ulangan. Faktor pertama adalah tepung bagian tanaman, yaitu rhizome, batang, daun, dan akar. Faktor kedua adalah konsentrasi ekstrak, yaitu $0,0 \% ; 0,5 \% ; 1 \%$, dan 1,5\%. Peubah yang diamati adalah diameter koloni dan kepadatan spora $P$. capsici. Hasil percobaan menunjukkan bahwa setiap konsentrasi serbuk akar paling efektif dalam menekan diameter koloni dibandingkan dengan serbuk bagian yang lain, kecuali pada konsentrasi 1,5\%. Pada konsentrasi 1,5\%, serbuk akar dan rhizome mempunyai efektivitas yang sama. Secara khusus, untuk serbuk rhizome dan akar semakin tinggi konsentrasi semakin efektif dalam menekan diameter koloni $P$. capsici. Hasil penelitian juga menunjukkan bahwa pada konsentrasi 0,5\%, serbuk rhizome dan daun lebih efektif dalam menekan produksi zoospora dibandingkan dengan serbuk batang dan akar; rhizome dan daun mempunyai efektivitas yang sama. Pada konsentrasi 1 dan 1,5\%, serbuk rhizome, daun, dan akar lebih efektif dalam menekan produksi zoospora dibandingkan dengan serbuk batang; rhizome, daun, dan akar mempunyai efektivitas yang sama. Secara khusus, pada rhizome dan akar, semakin tinggi konsentrasi semakin efektif dalam menekan produksi zoospora P. capsici.
\end{abstract}

Key words: Alpinia galanga, Phytophthora capsici, black pepper

\section{INTRODUCTION}

Phytophthora capsici Leionian is destructive pathogen on many plants (Erwin \& Ribeiro, 1996). The pathogen causes spot on leaves and root rot of black pepper. The most destructive symptom happened when the attack reach the foot. Black pepper is an important crop in Indonesia, especially in Lampung Province. Although black pepper is subject to many diseases, foot rot is the most insidious and the most important of these on world wide basis. The disease can be widespread in the field and cause significant yield loss.

Foot rot was first reported from Indonesia in 1885 and has become limiting factor to the succesfull cultivation of black pepper in several country. Losses of 40 to $50 \%$ caused by foot rot have been reported in some black pepper plantations (de Waard, 1980, 1986 in Erwin \& Ribeiro, 1996). The pathogens damaged $80 \%$ of black pepper plantations throughout Indonesia (Asnawi \& Hasanah, 1997). Before the second world war, Indonesia exported more than $80 \%$ of world demand. In the year 1970, black pepper production in
Indonesia only enough for $30 \%$ of world demand. And in the next years, black pepper production in Indonesia was low, only 526/ha on the average. The other black pepper producing countries like Brazil and Malaysia produce $3000 \mathrm{~kg} / \mathrm{ha}$ on the average (Wahid \& Suparman, 1986).

Traditionally, fungicides and resistance cultivars have been used to manage these diseases in the field. (Ristaino et al., 1997). Erwin and Ribeiro (1996) recommend that the first step of foot rot control is planting on well-drained sites not previously grown to black pepper for at least for 1 year. After the disease is detected, removing the diseased vines and treating the soil around the diseased roots with a suitable fungicide like Bordeaux mixture, metalaxyl, and fosetyl-Al

In commercially grown cultivars of $P$. nigrum, a high degree of resistance is lacking, but different degrees of tolerance are detectable by stem lesion and root rot rating systems (Nambiar et al., 1991 in Erwin \& Ribeiro, 1996). This fact is supported by Asnawi and Hasanah (1997).

\footnotetext{
${ }^{1}$ Lecturer of Plant Pathology, Departement of Plant Protection Lampung University
} 
In Indonesia, foot rot is still become a serious problem. The use of synthetic fungicides is not suitable for small farmers. The stop of famers' subsidi to buy fungicides has made an increase of fungicide price, so famers can not buy. Beside, the use of synthetic fungicides in the long run cause negative side effects. All synthetic fungicides leave residue in nature. An important group of fungicides as phenylamides (metalaxyl and related compounds) cause Phytophthora resistant to the fungicides. Fungi in the genus Phytophthora frequently develope virulent races that can overcome single gene resistance in plants (Umaerus et al., 1983), and insensitivity to phenylamide fungicides such as metalaxyl has been reported (Milgroom \& Fry, 1989 cit. Ristaino et al., 1997)

It is important to look for other alternative control other than synthetic chemicals. Natural products like plant fungicides give promising solution. Ginting et al. (2000) reported that there were 9 plant powders those effectively decreased colony diameter of $P$. capsici. One of them is A. galanga. So, this research was conducted to evaluate in detail the effects of $A$. galanga on the growth and reproduction of $P$. capsici in vitro.

\section{METHODS}

The factorial experiment $(4 \times 4)$ was conducted in the laboratory of Plant Protection Department, Lampung University from February to June 2001. The experiment consisted of two factors. The first factor (plant parts) were leaves, stems, roots, and rhizome powder. The second factor (powder concentrations) were $0 ; 0.5 ; 1$; and $1.5 \%$. The treatments were arranged in randomized completely design with 3 replicates. The investigated variables were colony radius and zoospore density of $P$. capsici. The data were analysed with anova. The data homogenity was tested with Bartlett test. The mean separation was tested with least significant different. All testings were conducted at 5\% significant level.

Plant parts (leaves, stems, roots, and rhizome) were washed with tap water and cut to be smaller parts. The smaller parts were dried by room temperature and then ovened $50^{\circ} \mathrm{C}$ for 4 days. The dried smaller parts were grind to be powder with blender. The powder was kept at $5^{\circ} \mathrm{C}$ before used.

$P$. capsici was isolated from diseased leaf. Diseased leaf was cut to be smaller parts at the border of diseased tissue and healthy tissue. The smaller leaf parts were planted on PDA in a petri and incubated for 5 days. The tip of the coming colony was cut and transferred on PDA in an other petri and incubated for a week.

Plant powder was applied in PDA according to food poisoned method $P$. capsici was taken with small borer (1 cm diameter) and transferred to the treated media. The colony radius were measured 5 days after infestation, while zoospore densities were counted two weeks after infestation with haemacytometer.

\section{RESULT AND DISCUSSIONS}

The $\mathrm{r}$ esults of the experiment showed that generally all tipes of A. galanga powder decreased colony radius of $P$. capsici ( Table 1 ).

Tabel 1. The effects of A. galanga on colony radius (mm) of P. capsici five days after infestation

\begin{tabular}{ccccc}
\hline \multirow{2}{*}{ Concentration (\%) } & \multicolumn{4}{c}{ Tipes of Powder } \\
\cline { 2 - 5 } & Rhizome & Stems & Leaves & Roots \\
\hline 0.00 & $41.17 \mathrm{a}$ & $41.50 \mathrm{a}$ & $40.83 \mathrm{a}$ & $41.33 \mathrm{a}$ \\
& $\mathrm{D}$ & $\mathrm{B}$ & $\mathrm{A}$ & $\mathrm{D}$ \\
0.50 & $39.33 \mathrm{~b}$ & $41.00 \mathrm{c}$ & $41.83 \mathrm{c}$ & $32.83 \mathrm{a}$ \\
& $\mathrm{C}$ & $\mathrm{AB}$ & $\mathrm{A}$ & $\mathrm{C}$ \\
1.00 & $30.00 \mathrm{~b}$ & $40.00 \mathrm{c}$ & $41.00 \mathrm{c}$ & $26.00 \mathrm{a}$ \\
& $\mathrm{B}$ & $\mathrm{A}$ & $\mathrm{A}$ & $\mathrm{B}$ \\
1.50 & $21.00 \mathrm{a}$ & $40.00 \mathrm{~b}$ & $40.83 \mathrm{~b}$ & $20.00 \mathrm{a}$ \\
& $\mathrm{A}$ & $\mathrm{A}$ & $\mathrm{A}$ & $\mathrm{A}$ \\
\hline
\end{tabular}

Notes: numbers followed by the same letters are not significantly different according to LSD test $(\alpha=0.05)$. Capital letters are read vertically, and small letters are read horizontally. 
Table 2. The effect of A. galanga on sporangia number of $P$. capsici five days after infestation

\begin{tabular}{ccccc}
\hline \multirow{2}{*}{ Concentration (\%) } & \multicolumn{4}{c}{ Tipes of Powder } \\
\cline { 2 - 5 } & Rhizomes & Stems & Leaves & Roots \\
\hline \multirow{2}{*}{0.00} & $9.26 \mathrm{a}$ & $9.41 \mathrm{a}$ & $8.42 \mathrm{a}$ & $10.13 \mathrm{a}$ \\
& $\mathrm{C}$ & $\mathrm{B}$ & $\mathrm{B}$ & $\mathrm{C}$ \\
0.50 & $5.53 \mathrm{a}$ & $8.76 \mathrm{~b}$ & $3.82 \mathrm{a}$ & $7.65 \mathrm{~b}$ \\
& $\mathrm{~B}$ & $\mathrm{~B}$ & $\mathrm{~A}$ & $\mathrm{~B}$ \\
1.00 & $1.15 \mathrm{a}$ & $7.87 \mathrm{~b}$ & $2.63 \mathrm{a}$ & $3.02 \mathrm{a}$ \\
& $\mathrm{A}$ & $\mathrm{B}$ & $\mathrm{A}$ & $\mathrm{A}$ \\
1.50 & $0.96 \mathrm{a}$ & $5.50 \mathrm{~b}$ & $2.04 \mathrm{a}$ & $1.71 \mathrm{a}$ \\
& $\mathrm{A}$ & $\mathrm{A}$ & $\mathrm{A}$ & $\mathrm{A}$ \\
\hline
\end{tabular}

Notes: numbers followed by the same letters are not significantly different according to LSD test $(\alpha=0.05)$. Capital letters are read vertically, and small letters are read horizontally.

Roots powder was the best to decrease colony radius of $P$. capsici compared to the others at every concentration, but $1.50 \%$; at this concentration, the effectivity of roots powder and rhizome powder were the same and better than stems and leaves powder. The effectivity of rhizome powder was better than stems and leaves at every concentration tested. Table 1 also shows that on roots and rhizome powder, the higher the concentration the higher the capability of the powder to decrease colony radius. These results indicate that roots powder contain more active ingredients than the others; and rhizome powder contain more active ingredients than stems and leaves powder.

The results of the experiment also showed that generally all tipes of $A$. galanga powder decreased the number of sporangium (Table 2). Stems powder was the worst at concentration 1.00; and $1.50 \%$ ); at concentration $0.50 \%$ stems powder and roots powder were not significantly different. At concentration 1.00 and $1.50 \%$, the effectivity of roots, rhizome and leaves powder to decrease the number of sporangium were the same. The lowest capability of stem powder to decrease number of sporangia may due to lowest content of active ingredients. The higher the concentration of the powder was not followed by the higher the effectivity of the powder to decrease the number of sporangium. Roots, rhizome, and leaves powder decreased number of sporangia at low $(0.50 \%)$ concentration, but stem powder only effective at high concentration (1.50\%).

It seemed that the active ingredients which decreased colony radii and number of sporangia were not the same. It is indicated by the fact that the substance which decreased colony radius operate effectively at low concentration in roots and rhizomes powder only, but the substance which decreased number of sporangia operate effectively at low concentration in roots, rhizome, and leaves powder.

\section{CONCLUSION}

All types of Alpinia galanga powder decreased colony radii and sporangia number of $P$. capsici. The effectivity of roots powder to decrease colony radius was the best compared to the others and the higher the concentration the higher the effectivity of roots and rhizomes powder to decrease colony radius. Roots and rhizome powder effectively decreased colony radius at low concentration. Roots, rhizome, and leaves powder effectively decreased number sporangia at low $(0.50 \%)$ concentration. Stems powder decreased effectively number of sporangia only at high (1.50\%) concentration.

\section{REFERENCES}

Asnawi, R. \& Hasanah. 1997. Uji ketahanan beberapa varietas lada terhadap Phytophthora palmivora (Butl.). Jurnal Fitopatologi IV (01): 18-22.

Erwin, D.C. \& O.K. Ribeiro. 1996. Phytophthora Diseases Worldwide. American Phytopathological Society. St. Paul. MN. 
Ginting, C., D.R.J. Sembodo, H. Susanto, \& M.P. Yufdy. 1999. Kemampuan beberapa serbuk tumbuhan dalam menekan pertumbuhan Phytophthora capsici dari tanaman lada. Halaman 512-518 dalam Prosiding Kongres Nasional XV dan Seminar Ilmiah PFI Purwokerto, Indonesia.

Ristaino, J.B., G. Para, \& C.L. Campbell. 1997. Suppression of Phytophthora blight in Bell pepper by a no-till wheat cover crop. Phytopathology 87: 242-249.

Umaerus, V., M. Umaerus, L. Erjefalf, \& B.A. Nilsson. 1983. Control of Phytophthora by host resistance: Problems and progress. Pages 315326 in Phytophthora: Its Biology, Taxonomy, Ecology and Pathology. D.C. Erwin, BartnickiGarcia, \& P.H. Tsao (eds.). The American Phytopathological Society. St. Paul, MN. 
Tabel 1 . The effects of A. galanga on colony radius (mm) of $P$. capsici five days after infestation

\begin{tabular}{ccccc}
\hline Concentration (\%) & \multicolumn{4}{c}{ Tipes of Powder } \\
\cline { 2 - 5 } & Rhizome & Stems & Leaves & Roots \\
\hline 0.00 & $41.17 \mathrm{a}$ & $41.50 \mathrm{a}$ & $40.83 \mathrm{a}$ & $41.33 \mathrm{a}$ \\
& $\mathrm{D}$ & $\mathrm{B}$ & $\mathrm{A}$ & $\mathrm{D}$ \\
0.50 & $39.33 \mathrm{~b}$ & $41.00 \mathrm{c}$ & $41.83 \mathrm{c}$ & $32.83 \mathrm{a}$ \\
& $\mathrm{C}$ & $\mathrm{AB}$ & $\mathrm{A}$ & $\mathrm{C}$ \\
1.00 & $30.00 \mathrm{~b}$ & $40.00 \mathrm{c}$ & $41.00 \mathrm{c}$ & $26.00 \mathrm{a}$ \\
& $\mathrm{B}$ & $\mathrm{A}$ & $\mathrm{A}$ & $\mathrm{B}$ \\
1.50 & $21.00 \mathrm{a}$ & $40.00 \mathrm{~b}$ & $40.83 \mathrm{~b}$ & $20.00 \mathrm{a}$ \\
& $\mathrm{A}$ & $\mathrm{A}$ & $\mathrm{A}$ & $\mathrm{A}$ \\
\hline
\end{tabular}

Notes: numbers followed by the same letters are not significantly different according to LSD test at 0.05 level. Capital letters are read vertically, and small letters are read horizontally.

Table 2. The effect of A. galanga on sporangia number of $P$. capsici five days after infestation

\begin{tabular}{ccccc}
\hline Concentration (\%) & \multicolumn{4}{c}{ Tipes of Powder } \\
\cline { 2 - 5 } & Rhizomes & Stems & Leaves & Roots \\
\hline \multirow{2}{*}{0.00} & $9.26 \mathrm{a}$ & $9.41 \mathrm{a}$ & $8.42 \mathrm{a}$ & $10.13 \mathrm{a}$ \\
& $\mathrm{C}$ & $\mathrm{B}$ & $\mathrm{B}$ & $\mathrm{C}$ \\
0.50 & $5.53 \mathrm{a}$ & $8.76 \mathrm{~b}$ & $3.82 \mathrm{a}$ & $7.65 \mathrm{~b}$ \\
& $\mathrm{~B}$ & $\mathrm{~B}$ & $\mathrm{~A}$ & $\mathrm{~B}$ \\
1.00 & $1.15 \mathrm{a}$ & $7.87 \mathrm{~b}$ & $2.63 \mathrm{a}$ & $3.02 \mathrm{a}$ \\
& $\mathrm{A}$ & $\mathrm{B}$ & $\mathrm{A}$ & $\mathrm{A}$ \\
1.50 & $0.96 \mathrm{a}$ & $5.50 \mathrm{~b}$ & $2.04 \mathrm{a}$ & $1.71 \mathrm{a}$ \\
& $\mathrm{A}$ & $\mathrm{A}$ & $\mathrm{A}$ & $\mathrm{A}$ \\
\hline
\end{tabular}

Notes: numbers followed by the same letters are not significantly different according to LSD test at 0.05 level. Capital letters are read vertically, and small letters are read horizontally. 